\title{
When Will WTO Membership Signal Commitment to Free Trade by A Developing Country
}

\author{
S. Mansoob Murshed \\ Institute of Social Studies
}

\begin{abstract}
A signalling game involving three parties: a developing country, the WTO and a developed country is outlined. The developing country might be tempted to renege or deviate from free trade. Although the costs of reneging from free trade result in a loss of credibility, the costs come in the future and are discounted. Short-term gains include revenues from import taxes that are important to the public finances of low-income countries. Membership of a rules based organisation such as the WTO can act as a credible commitment device. In these circumstances, however, the South's commitment to free trade depends upon a clear signal from the North that it too is committed to free trade. Otherwise the South will continue to deviate from optimal and freer trade policies.
\end{abstract}

- JEL Classifications: C72, D84, F13

- Key words: WTO, North-South trade, Commitment, Delegation

\section{Introduction}

Trade liberalisation and export promotion are nowadays widely regarded as the sine qua non of a successful development and growth strategy. Part of this outward oriented strategy involves commitment to free trade. This commitment needs to be signalled to important markets and trading partners, particularly in the North. Otherwise, there is the danger of the excessive use of contingent protection by major trading partners. Access to important markets may be restricted. Also,

*Corresponding address: S. Mansoob Musrshed, Institute of Social Studies (ISS), PO Box 29776, 2502 LT 
trade liberalisation and a commitment to free trade are often conditions for project aid and budgetary support on the part of both bilateral and multilateral donors. Furthermore, free trade policies are also felt to be conducive to foreign direct investment (FDI) inflows in developing countries that do not already have large stocks of FDI and a vast domestic market. Finally, free trade policies may be optimal in there own right. Despite strategic trade policy arguments against free trade, these may be difficult to implement and subject to capture by non-altruistic special interest groups.

It has to be pointed out in this connection that protectionism in the North towards the exports of the South has been growing since the early 1970s, see Murshed (1992). These protectionist tendencies are greatest whenever the South acquires competitiveness and market share in a new area of manufacturing. It is also easier to impose trade restrictions against exports originating in the South, as practically no individual country in the developing world can meaningfully retaliate. A good example is the multi-fibre agreement (MFA) which governs the import of textiles and apparel from the South to the North. Although the MFA is meant to be phased out, it still remains to be seen whether this will occur at the target date set. In addition to that there are at least three other developments jeopardising developing country market access in the North in terms of manufactured goods exports. The first is the pauper labour argument, the contention that free trade in manufacturing with the South disadvantages unskilled (or production line) workers in import competing sectors in the North, see Bhagwati (1994). The second is to do with environmental and labour standards that must be incorporated into the exports of the South. The third is related to the fact that many developing countries are using contingent protection instruments, such as anti-dumping actions, against other developing countries, see Tharakan (2002). The biggest problem lies in the fact that the developed North does not liberalise trade with the South in areas that count the most for the South, such as with agriculture and textiles.

Given these dangers of contingent and other forms of protection it is important to have credible commitment devices to free trade for the South that at least restrain protectionist tendencies in the North and allow developing countries to fulfil aid conditionality in connection with trade policies. Without such commitment technologies that tie a typical developing country to free trade, the temptation to protect might be greater in partner countries. This is where the World Trade Organisation (WTO) enters the picture. Most developed countries are members of 
the WTO. WTO rules require the granting of most favoured nation status, except under certain derogations (which are felt by many to leave excessive loopholes). The question then is whether or not the WTO can act as credible commitment device that minimises the costs of reneging on commitments to free trade.

It can be argued that the WTO is not about promoting free trade, but rules-based managed trade. For the South this means less discretionary trade policy and more rules governing import controls. It is, therefore, a movement towards free trade, a trend that we actually observe. So, as far as the South is concerned, we can speak of the WTO mechanism and free trade. By contrast, in the North there are residual powers regarding trade policy, especially when directed against imports from the South. Trade policy may become an alternative to the older discretionary monetary and fiscal policies that are fast falling into disuse. In other words, trade policy, particularly vis-à-vis the South, may be the new form of discretionary macroeconomic policy designed to bolster employment and output in "sunset" industries. This occurs in the context of asymmetric economic power relations between the North and South.

The purpose of this paper is to develop a simple signalling game involving three parties: a developing country, the WTO and a developed country. The role of the WTO is passive; it acts as an anchor for commitments to freer trade. Without it the developing country might be tempted to renege or deviate from free trade. Although the costs of reneging from free trade result in a loss of credibility and retaliation by other trading partners and donors, the costs come at some future date that might be discounted by policy makers with a short time horizon. Short-term gains include revenues from import taxes that are so important to the public finances of low-income countries. Thus commitments to free trade under these circumstances are incentive incompatible or time inconsistent and are therefore not credible. Membership of a rules based organisation such as the WTO can act as a credible commitment device. This is because of the visible costs of deviating from the WTO rules about free trade. These costs take the form of trade sanctions and the possible removal of most favoured nation status. But there is an added problem here. The costs that in itself act as a commitment technology depend on the imposition of sanctions only in the event of the country breaking WTO rules. But powerful countries in the North often impose protectionist measures against imports from the South, acting in national self interest, and in infringement of the "spirit" of WTO rules. These make the WTO sanctions that, after all, work through trade retaliation less credible to the developing country. In the model the 
developing countrys perceptions about the effectiveness of WTO sanctions will depend on what it believes the attitudes of powerful trade blocs in the North are with respect to its exports. Beliefs about the North become important. Therefore, success of the WTO system also depends on the reputation of its more powerful Northern members regarding free trade.

The rest of the paper is organised as follows. Section 2 examines the lack of credibility to a commitment to free trade in the South when its government might be tempted to renege on its free trade commitments in order to raise revenue. Section 3 examines the role of the WTO as a commitment device by delegation for the South. Section 4 analyses the role of the North, and its imperfect commitment to free trade, upon which the Souths commitment is conditional. Finally, section 5 concludes.

\section{Credibility of Free Trade Policies in Developing Countries}

The basic set up of the model in this section follows from Addison and Murshed (2002), involving two sides whom we refer to as the public in a developing nation (W) and the developing country government (S). It has similarities to the inflation control policy games literature, see Barro-Gordon, 1983, Backus-Driffill, 1985 and Cukierman, 2000, among others. A similar model can also be found in Staiger (1995), where a group of nations enter into a cooperative agreement to lower tariffs, but individual nations may still be tempted to renege on the agreement.

The public, like a rules based organisation such as the WTO, dislikes deviations from policy commitments regarding trade policies and trade taxes. This is because deviations from pre-announced policies preclude intertemporal tax saving behaviour on the part of the public. The developing country government in question may, however, have something to gain from protection, above all from trade policies that are of a surprise nature and prevent tax saving or evading action. This is because import taxes are an important and crucial source of revenue for developing countries. Consider the utility function of the developing country government $\left(U^{S}\right)$ :

$$
U^{S}=(1 / 2) c_{1} t^{2}+E \theta c_{2}\left(t-t^{e}\right)
$$

where $c_{1}>0, t, t^{e}, \theta, c_{2} \geq 0$.

$\theta=B+\varepsilon, B \geq 0$ 
$\varepsilon=\varepsilon_{t-1}+\eta, \eta\left(0, \sigma^{2}\right)$

In equation 1 and what follows the utility functions correspond to expected utilities. The expectation operator $(E)$ is introduced for the value of a random variable within the function, and a superscript $e$ is used for an expectation of a variable on which information is incomplete. The first term on the right-hand side of equation (1) is the pure or distortionary cost of protection for the economy. It is in quadratic (squared) form, where $t$ represents a tariff or its quota equivalent, and $c_{l}$ is the parameter measuring the direct cost of protection. The negative sign before it is to indicate the cost of protection in relation to distorting the economy in terms of general equilibrium resource misallocation. This rises more than proportionately as the level of $t$ rises. The parameter (1/2) is introduced for analytical tractability.

The second term on the right hand side of (1) indicates the gains to the government in the South from reneging on a free trade agreement, or the benefit from surprise protection, where the level of actual protection $(t)$ exceeds the level of protection expected by the public $\left(t^{e}\right)$. Surprise protection may take the form of unannounced taxes on imports, on the grounds of some economic exigency. Nevertheless it fills the coffers of the government of the day. They may utilise it to pursue pet projects that redistribute income to its support group, or allow its followers to extract rents through holding import licences, or profit from supplying domestic substitutes for imports. The parameter $c_{2}$ captures the magnitude of this gain to the government of the day; the higher is $c_{2}$ the greater is the gain from surprise protection. It may also be viewed as a subjective measure of the voracity of the government. In addition to this the greater are the prospects for rent extraction and/or profits from supplying domestic substitutes, the higher is the gain from surprise protection. This is measured by the expected value $(E)$ of the parameter $\theta$, which captures the rent and profits $(B)$ from holding import licenses and supplying import competing goods. The rent or profit is subject to random shocks $(\varepsilon)$ with a first-order auto-regressive process resulting in shocks persisting for some time. The purely random component $(\eta)$ has zero mean and constant variance. Random shocks could arise from terms of trade fluctuations or domestic supply shocks. Note also that the purely distortionary costs of protection and gains from surprise trade taxes are additive separable.

As far as the gains from surprise protection are concerned it is part of a process 
of income or revenue generation for the government in the South $\left(y^{S}\right)$ described as:

$$
y^{S}=y+E \theta\left(t-t^{e}\right)
$$

Here the revenues for the government are equal to some fixed or natural rate $(y)$ plus an additional component arising from surprise trade taxes. The process described in (2) is similar to the Lucas aggregate supply relationship. The income associated with the natural rate is received with certainty under free trade. In contrast, the gains from the surprise element are based upon driving a wedge between actual and expected levels of trade taxes, so as to minimise tax saving behaviour. It also means that if $y^{S}$ is to be augmented above the natural rate, it has to come via surprises. Hence only the second term in the right hand side of (2) is incorporated in (1).

The government maximises utility in (1) subject to $t$, which leads to optimal $t^{*}$ :

$$
t^{*}=E \theta c_{2} / c_{1}
$$

This result can be interpreted in the following manner: the equilibrium choice of protection is greater the higher is the element of avarice, $c_{2}$, the higher the expected availability of rents and profits from trade restrictions, $\theta$, and the smaller is the purely distortionary impact of protection, $c_{l}$.

As far as the public (W) is concerned, a simple version of their utility function is:

$$
U^{W}\left(t^{e} / t\right)=-\left(t-t^{e}\right)^{2}
$$

The meaning of (4) is that the publics utility is declining in surprise protection, when $t$ diverges from $t^{e}$. Maximising (4) with respect to $t^{e}$ yields:

$$
t=t^{e}
$$

The public reacts at the same time as the government. Substituting (3) into (1) for the government, and (5) in to (4) for the public yields:

$$
\begin{gathered}
U^{S}=-\left(E \theta c_{2}\right)^{2} / 2 c_{1} \\
U^{W}=0
\end{gathered}
$$

This is the outcome when both announcements by the government regarding their trade policy and expectations formation by the public take place 
simultaneously. What if the government pursues a policy of free trade with $t=0$ ? Then:

$$
\begin{gathered}
U_{P}^{S}=0 \\
U_{P}^{W}=0
\end{gathered}
$$

This is the Pareto optimal outcome and superior to the result in (6).

Now let us assume that the government in the South has a first mover advantage and can announce free trade and then engage in surprise protection. In that case the actual and expected levels of protection diverge, $t=E \grave{e} c_{2} / c_{1}$ and $t^{e}=0$ in equation (1). This involves cheating on a pre-announced commitment:

$$
U_{C}^{S}=\left(E \theta c_{2}\right)^{2} / 2 c_{1}
$$

Note that the governments utility is greater in this case than under (6). At this juncture we introduce reputation. Following Barro \& Gordon (1983) the reputation of the government is all or nothing, and it hinges on its behaviour in the past. Consider the following rule. The public believes the announcement if the government acted honestly in the previous period and kept its commitments. Otherwise it is not believed, and its actions are predicted to be opportunistic. This implies that there exists a future cost of cheating. The cost is equal to the loss of reputation and the inability to create surprises, but this cost $(\mathrm{C})$ is in the future and is given by:

$$
C=-\left(\left(E \theta c_{2}\right)^{2} / 2 c_{1}\right)
$$

Hence the penalty for cheating (which is the loss of reputation) appears to exactly equal the gain from cheating in (8). But the punishment comes at some future date. If the government discounts this future loss, the cost of cheating is always less than the gain from reneging on a fixed commitment. Typically in many developing countries the future is heavily discounted, especially by government. The upshot is that the socially optimal policy of zero trade taxes ( $t=$ 0 ) is time inconsistent or incentive incompatible, and thus will not be a possible outcome. The optimal policy of no conflict is infeasible, as it is not consistent with the incentives and expectations of the parties to the game. More particularly, the public knows it is in the interests of the government to renege on a pre-announced policy of free trade, and thus will not find any such commitment credible.

Furthermore, there will be a range of possible tariff or trade tax intensities that 
are feasible, implying multiple equilibria. The results are depicted in figure 1 in $y^{S}$ and $t$ space. The upward sloping linear aggregate supply curve has a slope exactly equal to $E \grave{e}$, from equation (2), and is steeper the greater the availability of rents or profits from trade restriction. The government's preferences are shown by the concave indifference curves with a slope $=E \theta c_{2} / c_{1}$, obtained from (1). The more anxious is the government to extract rents (the greater is $\theta c_{2}$ ), the steeper is the indifference curve. The government could announce zero tariffs at point $\mathrm{A}$. It could then cheat on its commitment and try to move to point $\mathrm{B}$. The aggregate supply curve schedule would shift leftwards because of the process of expectations formation. The vertical distance between $\mathrm{B}$ and $\mathrm{C}$ gives the range of multiple equilibria depending on the time horizon of the game and the discount rate used to obtain the present value of future reputation losses. The point B defines the lowest feasible tariff rate. Following Barro \& Gordon (1983), it is described as the best enforceable outcome. An increase in the expected profits from tariffs, $E \theta$, shifts the aggregate supply function leftwards and makes the indifference curves steeper pointing to an expansion in the feasible range of trade taxes. Note that this could arise due to random fluctuations on $\theta$. Also situations where the future is heavily discounted are likely to raise the tariff threshold associated with the best enforceable outcome.

Figure 1. Surprise trade policies

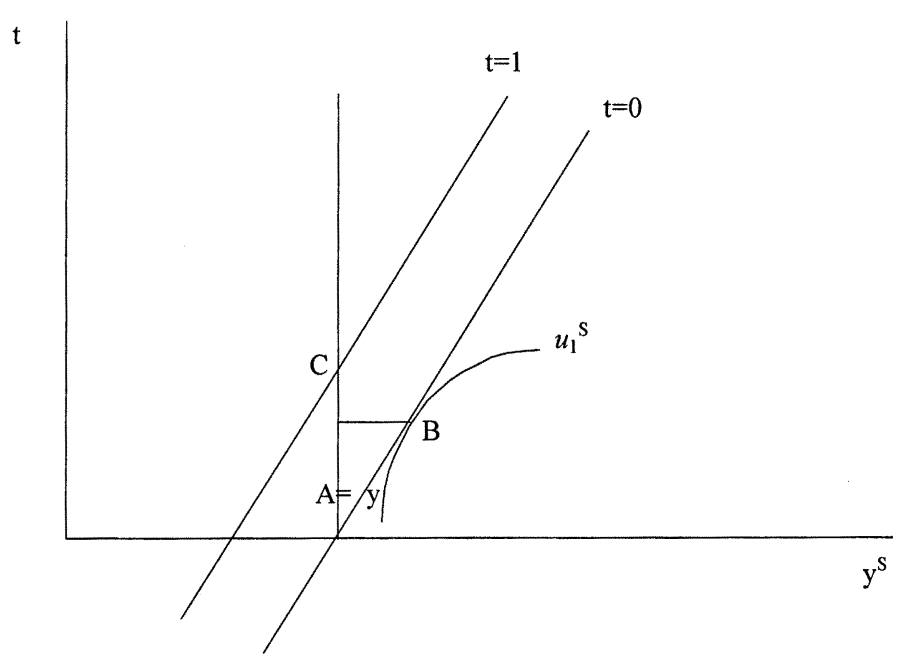




\section{Commitment Technologies for the Government in the South}

The problems noted in the previous section are to do with the credibility of preannounced commitments and sustaining these commitments. This problem is especially acute when it comes to sovereign governments, as its pronouncements or commitments are not enforceable. Reneging on pre-announced policy statements by government and politicians has been described as opportunistic behaviour by Dixit (1996). It arises in the context of repeated interactions where commitment is precluded by transaction-cost politics. One way of ensuring commitment is through effective constitutional safeguards that bind the government, see Schelling (1960) for an early discussion of locking-in mechanisms. Alternatively, the government may delegate its powers to another credible body. The transfer of the power of taxation from the king to a representative parliament is the best historical example. Commitment may be achieved by delegation, and the macroeconomic policy literature is replete with examples, see Dixit (1996) for a survey. A further alternative is delegation of powers via membership of a supra-national or international agreement and treaty such as the WTO. Bagwell and Staiger (1999) model a process such as WTO membership as sustaining commitment to optimal trade policies. But the government may not want to delegate all its powers away, and could wish to retain some residual powers in certain contingencies. The membership of WTO is not a commitment to free and unfettered trade, for example, and there are several derogations and contingencies via which a state may escape granting most favoured nation (MFN) status to its trading partners.

Consider a reformulated version of the Southern governments utility function where we embed an external commitment via a treaty such as WTO membership, as well as direct retaliation from its more powerful trading partners in the North:

$$
U^{S}=-(1 / 2) c_{1} t^{2}+E \theta c_{2}(A)\left(t-t^{e}\right)-c_{3}(T)\left(t-t^{e}\right)
$$

where: $c_{1}>0, c_{2} \geq 0 ; c_{31}>0 ; c_{21}<0$

Also: $c_{2}(A) \geq c_{2} \forall A, c_{3}(T) \geq 0 \forall \tau^{e} \leq 0, c_{3}(T)<0 \forall \tau^{e}>0$

In equation (10) the behavioural parameters of the government, $c_{2}$ and $c_{3}$ are altered via delegation to the WTO process. The parameter $c_{2}$ is made a function of $A$, the WTO dispute settlement sanction if the government in the South violates 
agreements that do not fall into the purview of WTO accepted contingent protection.

The last term in (10) is an additional term when compared to equation (1), it represents a commitment technology or delegation, and $c_{3}$ measures the costs of reneging on trade agreements as a function of sanctions $(T)$ imposed by powerful Northern trading partners such as the European Union (EU) and the United States operating through or outside WTO rules. The sanction works if and only if the Northern trading partner itself pursues free trade, and its tariffs or other protective instruments against the South, $\tau$, are non-positive. In other words, free trade in the North is a signal of an effective sanction against non-compliance with regard to free trade commitments in the South. Otherwise the WTO process can be counterproductive in binding and committing a typical country in the South to free trade. For example compliance with agreements such as TRIPs and TRIMs by the South may become more lukewarm if there is poor progress in freeing up developing country access to Northern markets.

In general, the combined effect of both $c_{2}$ and $c_{3}$ will result in the indifference curve in Fig. 1 flattening out, and lower equilibrium ranges of trade restrictions will emerge.

Maximising (10) with respect to $t$ yields the optimum level of $t$ with commitment $\left(t_{c}^{*}\right)$ :

$$
t_{c}^{*}=\left(E \theta c_{2}-c_{3}\right) / c_{1}
$$

Proposition 1: The presence of external commitment technologies in the form of WTO membership and other trade sanctions lowers the optimal level of trade restrictions pursued by the government in the South if and only if $c_{3}>0$ implying $\tau \leq 0$.

The proposition can be verified by noting that $t_{c}^{*}$ in (11) is less than $t^{*}$ in (3) if $c_{31}>0$. These commitment technologies lead to lower levels of protection when compared to (3).

\section{The Commitment to Free Trade in the North: Signal to the South}

In this section we are concerned with the signal that the North gives to the South 
regarding its own attitudes towards free trade. If the South perceives the North to be committed to free trade and expects the North's tariffs or quotas directed to the South to be negligible, it increases the South's own commitment to free trade as given by (10) and (11) above. This is of "real" importance because of the persistence, for example, of huge agriculture subsidies in the North that effectively shut out the Souths agricultural exports to the North. Another example concerns MFA. With regard to the MFA, there is a commitment by the North to abolish it; with agricultural subsidies some vague noises about their removal exist. The motivation for protection in the North is dissimilar to that in the South; it is not a revenue argument but rather offering protection to uncompetitive import competing sectors, see Murshed (1992). Many of these sectors lobby the government in the North (particularly in the USA) for protection. Powerful economic blocs in the North are also relatively free of effective trade sanctions.

Let there be honest $(\mathrm{H})$ and dishonest $(\mathrm{D})$ types of governments in the North, where the former are more dependable. The government in the South knows that there are two types of Northern governments, but is imperfectly informed about their true type. To improve on the Barro and Gordon (1983) view of $(0,1)$ reputation, we can make perceptions about the North's reputation based upon, and updated by using Bayes rule. A generic objective function for both types of Northern government can take the following form:

$$
U^{H, D}=-(1 / 2) c_{1} \tau^{2}+c_{2}\left(\tau-\tau^{e}\right)
$$

Here the first term on the right-hand side is the general economic distortion caused by protection (via $\tau$ ), and the second term represents the macroeconomic gains to the North in terms of employment gained in import competing sectors via surprise protection. Surprise protection cannot be ruled out in the North, for example President Bush's protection for steel in the USA. In many ways trade policy is a substitute for fiscal and monetary policy, which are nowadays increasingly subject to fixed rules.

The honest-type of Northern government maximises utility with respect to two constraints (see Cukierman, 2000). The first is a dependability constraint; the honest type wants to appear to be true to its word:

$$
\tau^{H}=\tau^{A}
$$

where the superscript $H$ stands for the dependable or honest type, $H$ 's 
announcements or offers are indicated by the superscript $A$. This constraint states that the actual outcome equals the announcement.

The other constraint concerns the Southern governments beliefs about the type of the Northern government. The Southern government will assign a probability, $\tilde{a}$ that the other side is the honest type, and a probability $1-\gamma$, that it is the dishonest type. The dishonest type always plays $c_{2} / c_{1}$, obtained from maximising (12) with respect to $\tau$. The Southern governments expectation of the level of trade restrictions will be a linear combination of the two strategies weighted by the corresponding probabilities:

$$
\tau^{e}=\gamma \tau^{A}+(1-\gamma)\left[c_{2} / c_{1}\right]
$$

Substituting (14) in (12), using (13), maximising with respect to $\tau^{H}$, yields:

$$
\tau^{H}=\tau^{A}=(1-\gamma)\left[c_{2} / c_{1}\right]
$$

Observe that even the 'better' type of Northern government engenders trade restrictions against the South, as it is also non-altruistic. Knowing the group to be non-altruistic, the government in the South will not regard over-optimistic pronouncements regarding free trade as a credible offer even from an honest type in the North. Levels of $\tau$ chosen in (15) vary proportionately with the poorness of equilibrium reputation, $(1-\gamma)$. The result in (15) is akin to classic adverse selection problems in insurance markets, where the high-risk type exerts a negative externality on the pooled contract offered to both risk categories.

Proposition 2: Given previous assumptions, if the government in the South is imperfectly informed about the type of its Northern counterpart then the level of protection is strictly positive for each type of Northern government.

This can be seen from (15): if $\tau=1, \tau^{H}=\tau^{A}=0$, and there is no protection. It amounts to perfect information on the Southern government side. With imperfect information about the type of government in the North, the South's commitment to free trade, and the commitment technology offered by the WTO in (10) and (11) will be non-functional. The South's commitment to free trade depends upon a clear signal from the North that it too is committed to free trade. Otherwise the South will continue to deviate from optimal and freer trade policies.

Corollary 2: The level of protection by the honest Northern type is zero, if and 
only if, the Southern government is fully informed about the North's type.

If there was full separation of the two types of Northern government, implying no uncertainty about the $\mathrm{H}$ or D-type, then $\gamma=1$ or 0 . Otherwise in the presence of uncertainty, the government in the South will use Baye's law to update its prior beliefs about the Northern government-type (see Cukierman, 2000 on how this operates). ${ }^{1}$ In that case, in period 2 , we will have:

$$
\gamma(2)=\frac{\gamma(1)}{\gamma(1)+(\gamma-\gamma(1)) p_{1}}
$$

In (16), two periods ( 1 and 2 for first and second) are indicated inside the parentheses. This is the equilibrium value of the probability of the Northern government being of the honest type in the second period of the game. It therefore captures reputational equilibrium, as it evolves, in a multiple period setting. It also states that reputation in the second period is higher the greater it was in the first period and the lower is the probability of type D pretending to be $H\left(p_{1}\right)$. Intuitively, this means a degree of path dependence or hysteresis in how reputation develops over time.

\section{Conclusion}

The analytical model in this paper has demonstrated that a commitment to freer trade, even if optimal, is fraught with temptations to renege on pre-announced commitments regarding freer trade by sovereign governments. For a developing country the attractiveness of deviations from free trade lie in the potential revenue earnings from protection. In a developed country, trade policy can act as a substitute for traditional counter-cyclical macroeconomic policies in an era when many Northern governments have delegated some discretionary macroeconomic policies away to independent bodies. The developing country's temptations to deviate from free trade may be restrained via membership obligations in a rules based supra-national authority such as the WTO. But this commitment by delegation crucially depends on how it perceives its powerful Northern trade partners will behave in connection with its own exports to countries in the North. If the North continues to be protectionist, as is the case at present, then WTO

\footnotetext{
${ }^{1}$ Equation (16) is the posterior probability that the Northern government is the $\mathrm{H}$ type, given that the $\mathrm{H}$
} type has been played in period 1 . 
membership will not be a successful commitment device to freer trade in the South.

This result is potentially important in the context of world trade negotiations, and is not just academic curiosia. The North continues to shut out the South from its markets in many important sectors such as textiles, agriculture and other areas where the South is gaining comparative advantage. In many instances, the device of contingent protection is employed. All of this occurs simultaneously as the North compels the South to open its markets to services and accept the TRIPs agreements, which may hamper domestic technological progress in the South. Ultimately, free trade should allow the South to access Northern markets, not just open up its markets to goods and services from the North. Low-income developing countries need to grow, and export promotion is part of the strategy of growth with macroeconomic stability and debt sustainability. Without greater access to Northern markets, the proposed millennium development goals with regard to poverty reduction cannot be reconciled with the needs for macroeconomic stability and debt reduction, which are also demanded by donors. In the final analysis, asymmetric trade policy power relations do not bode well for free trade. Countries in the South have in many instances unilaterally moved towards freer trade. Further developments in this regard will, however, be hampered without an equal commitment by countries in the North to free trade.

\section{Acknowledgments}

Paper prepared for the UNU/WIDER Project on the Impact of WTO Negotiations for low Income Countries. An earlier version of the paper was presented at the meeting on the project at Helsinki: $4^{\text {th }}-5^{\text {th }}$ October 2002.

Received 7 August 2003, Accepted 27 January 2004

\section{References}

Addison Tony and S. Mansoob Murshed (2002) Credibility and Reputation in Peacemaking, Journal of Peace Research, 39(4): 487-501.

Backus, David \& John Driffill (1985) Inflation and Reputation, American Economic Review 75(3): 530-8.

Bagwell, Kyle and Robert W Staiger (1999) An Economic Theory of GATT, American Economic Review, 89(1): 215-48. 
Barro, Robert and David Gordon (1983) Rules, Discretion and Reputation in a Model of Monetary Policy, Journal of Monetary Economics 12(1): 101-21.

Bhagwati, Jagdish (1994) 'Free Trade: Old and New Challenges', Economic Journal, 104 (423): 231-46.

Cukierman, Alex (2000) Establishing a Reputation for Dependability by Means of Inflation Targets, Economics of Governance 1(1): 53-76.

Dixit, Avinash K (1996) The Making of Economic Policy: A Transaction-Cost Politics Perspective. London: MIT Press.

Murshed, S Mansoob (1992) Economic Aspects of North-South Interaction: Analytical Macroeconomic Issues, London: Academic Press.

Schelling, Thomas C (1960) The Strategy of Conflict, Cambridge MA: Harvard University Press.

Staiger, Robert W (1995) International Rules and Institutions for Trade Policy, chapter 29 in Gene M Grossman and Kenneth Rogoff (eds), Handbook of International Economics, volume III, Amsterdam: North Holland.

Tharakan, Mathew (2002) The Problem of Contingent Protection in S Mansoob Murshed (ed) Globalization, Marginalization and Development, London: Routledge: 125-38. 